\title{
Erratum to: Robin Globus Veldman, Andrew Szasz, and Randolph Haluza-DeLay (eds): How the World's Religions are Responding to Climate Change: Social Scientific Investigations
}

Routledge Advances in Climate Change Research. Oxon, New York: Routledge, 2014. ISBN 978-0-415-64034-3, Price $\$ 155.00$ (hardback). xiv +327 pages, index

Willis Jenkins

Published online: 7 December 2014

(C) Springer Science+Business Media New York 2014

Erratum to: Hum Ecol (2014) 42:503-505

DOI 10.1007/s10745-014-9653-9

There was an error in one of the Editors' name in this review. The name was incorrectly written in the title as Robin Globus. The correct name should be Robin Globus Veldman. It has been corrected in this erratum.

The online version of the original article can be found at http:// dx.doi.org/10.1007/s10745-014-9653-9.

W. Jenkins $(\bowtie)$

Department of Religious Studies, University of Virginia, PO Box, 400126, Charlottesville, VA 22904-4126, USA

e-mail: willis.jenkins@virginia.edu 